\title{
Contribution of Pollution Prevention as a Green Supply Chain Practice-A Pilot Empirical Study of the Indian Automobile Manufacturing Sector
}

\author{
Mohd. Asif Gandhi ${ }^{1}$ \\ ${ }^{I}$ Department of Mechanical Engineering, Anjumain-I-Islam's Kalsekar Technical Campus, School of \\ Engineering and Technology, affiliated to University of Mumbai, India
}

\begin{abstract}
This paper tests empirically through a pilot study of the Indian Automobile Manufacturing Sector, the contribution of the variables constituting the construct Pollution Prevention in Green Supply Chain Practices. Also the paper establishes the reliability of the questionnaire instrument developed previously for measuring the construct Pollution Prevention and also for measuring the eleven variables that constitute the construct Pollution Prevention. Further the paper establishes the correlation among these eleven variables. Finally this paper conducts Confirmatory Factor Analysis (CFA) to arrive at one or more factors (linear combination of variables constituting the construct Pollution Prevention) to aid in measuring the construct Pollution Prevention.
\end{abstract}

Keywords: Automobile, CFA, Green Supply Chain Practice, Indian, Manufacturing Sector, Pilot Study, Pollution Prevention

\section{Introduction to Pollution Prevention and Green Supply Chain Practices}

Pollution Prevention has been identified as one of the five green supply chain practices having an influence over ten green supply chain performance measures [13]. Accordingly, this paper identifies the variables constituting the construct Pollution Prevention. Pollution Prevention in turn is a sub-construct of the main construct Green Supply Chain Practices. Since pollution prevention has been identified as being constituted of eleven variables, it is of interest to know how these eleven variables fare in the pilot empirical study of the Indian automobile manufacturing sector by means of a questionnaire instrument [13]. The 50 automobile manufacturing plants that were surveyed during the pilot empirical study are all listed in [4]. The survey methodology was used in line with the findings of [5].

\section{Research Questions}

The four research questions identified are as follows:

Research Question 1.To have a feel of the responses of the Indian Automobile Manufacturing Sector pertaining to the eleven variables constituting the construct Pollution Prevention.

Research Question 2.To know the reliability of the questionnaire instrument for measuring the construct Pollution Prevention.

Research Question 3.To know the reliability of the questionnaire instrument for measuring the eleven variables constituting the construct Pollution Prevention.

Research Question 4. How are the eleven variables constituting the construct Pollution Prevention correlated?

Research Question 5. How many factors are retained by the eleven variables constituting the construct Pollution Prevention?

III. The Construct And Variables Used In The Study

There are eleven variables that constitute the construct Pollution Prevention. They are depicted in the Table 1 in their abbreviated form.

Table 1. The eleven variables constituting the construct Pollution Prevention

\begin{tabular}{|l|l|l|l|l|l|l|l|l|l|l|l|}
\hline $\begin{array}{l}\text { The eleven variables } \\
\text { constituting the } \\
\text { construct Pollution } \\
\text { Prevention: }\end{array}$ & PP1 & PP2 & PP3 & PP4 & PP5 & PP6 & PP7 & PP8 & PP9 & PP10 & PP11 \\
\hline
\end{tabular}

The Descriptive Statistics Of The Data Scaled

A five point balanced Likert scale was used to scale the data from respondents on whom a questionnaire was administered. The respondents were employees of Indian automobile manufacturing firms and /or their plants as mentioned in [4]. The data collected revealed the following descriptive statistics of the eleven variables constituting the construct Pollution Prevention. 
Table 2. Descriptive Statistics of the data scaled by the questionnaire

\begin{tabular}{|c|c|c|c|c|c|c|}
\hline \multicolumn{7}{|c|}{ Simple Descriptive Statistics } \\
\hline Variable & $\mathbf{N}$ & Mean & Std Dev & Sum & Minimum & Maximum \\
\hline PP1 & 50 & 4.52000 & 0.93110 & 226.00000 & 1.00000 & 5.00000 \\
\hline PP2 & 50 & 4.52000 & 0.83885 & 226.00000 & 2.00000 & 5.00000 \\
\hline PP3 & 50 & 4.64000 & 0.69282 & 232.00000 & 2.00000 & 5.00000 \\
\hline PP4 & 50 & 4.46000 & 0.99406 & 223.00000 & 1.00000 & 5.00000 \\
\hline PP5 & 50 & 4.08000 & 0.89989 & 204.00000 & 1.00000 & 5.00000 \\
\hline PP6 & 50 & 4.72000 & 0.45356 & 236.00000 & 4.00000 & 5.00000 \\
\hline PP7 & 50 & 4.70000 & 0.50508 & 235.00000 & 3.00000 & 5.00000 \\
\hline PP8 & 50 & 4.10000 & 0.95298 & 205.00000 & 1.00000 & 5.00000 \\
\hline PP9 & 50 & 4.50000 & 0.86307 & 225.00000 & 2.00000 & 5.00000 \\
\hline PP10 & 50 & 4.46000 & 0.97332 & 223.00000 & 1.00000 & 5.00000 \\
\hline PP11 & 50 & 4.46000 & 0.99406 & 223.00000 & 1.00000 & 5.00000 \\
\hline
\end{tabular}

The Reliability Of The Instrument For The Variables And Construct Used

The reliability of the questionnaire instrument developed by [13] for the construct Pollution Prevention is shown in the Table 3 as 0.981131 which is considered to be excellent [7].

Table 3. Reliability by Cronbach's Coefficient Alpha for the construct Pollution Prevention

\begin{tabular}{|l|l|}
\hline Cronbach Coefficient Alpha \\
\hline Variables & Alpha \\
\hline Raw & 0.977275 \\
\hline Standardized & 0.981131 \\
\hline
\end{tabular}

The reliability of the questionnaire for the eleven variables that constitute the construct Pollution Prevention is shown in the Table 4 . All the eleven variables in Table 4 have a reliability greater than 0.9 which is considered to be an excellent indicator of internal consistency reliability of the questionnaire survey instrument [7].

Table 4. Reliability of the individual eleven variables constituting the construct Pollution Prevention

\begin{tabular}{|c|c|c|c|c|}
\hline \multicolumn{5}{|c|}{ Cronbach Coefficient Alpha with Deleted Variable } \\
\hline \multirow{2}{*}{$\begin{array}{c}\text { Deleted } \\
\text { Variable }\end{array}$} & $\begin{array}{c}|c| \\
\text { Raw Variables } \\
\text { Correlation } \\
\text { with Total }\end{array}$ & Alpha & $\begin{array}{c}\text { Standardized Variables } \\
\text { Correlation } \\
\text { with Total }\end{array}$ & Alpha \\
\hline PP1 & 0.831980 & 0.976678 & 0.829560 & 0.981089 \\
\hline PP2 & 0.971565 & 0.972584 & 0.975582 & 0.977267 \\
\hline PP3 & 0.914364 & 0.974784 & 0.914247 & 0.978885 \\
\hline PP4 & 0.976525 & 0.972420 & 0.974491 & 0.977296 \\
\hline PP5 & 0.861459 & 0.975688 & 0.848837 & 0.980591 \\
\hline PP6 & 0.818127 & 0.978844 & 0.827354 & 0.981146 \\
\hline PP7 & 0.796954 & 0.978609 & 0.801437 & 0.981813 \\
\hline PP8 & 0.867196 & 0.975722 & 0.856023 & 0.980404 \\
\hline PP9 & 0.972789 & 0.972480 & 0.975359 & 0.977273 \\
\hline PP10 & 0.915005 & 0.974324 & 0.917089 & 0.978811 \\
\hline PP11 & 0.976525 & 0.972420 & 0.974491 & 0.977296 \\
\hline
\end{tabular}

The Pearson's correlation coefficient among the variables used in the study

The Pearson's Correlation coefficient between different pairs of variables that constitute the construct Pollution Prevention is shown in the Table 5. Since all the values of correlation coefficient are around 0.7 and above, it indicates that all the eleven variables that make up the construct Pollution Prevention are oriented towards the goal of Pollution Prevention in a unidirectional manner. This is also an indicator of internal consistency reliability of the survey instrument ranging from acceptable to excellent [7]. Accordingly all the eleven variables are retained as there is also a strong support from existing literature in their favour [1], [2], [3], [6], [8], [9], [10], [11], [12] and [14].

Table 5. Pearson's Correlation coefficient

\begin{tabular}{|c|c|c|c|c|c|c|c|c|c|c|c|}
\hline \multicolumn{12}{|c|}{$\begin{array}{l}\text { Pearson Correlation Coefficients, } \mathrm{N}=\mathbf{5 0} \\
\text { Prob }>|\mathbf{r}| \text { under H0: } R \mathbf{R h o}=\mathbf{0}\end{array}$} \\
\hline & PP1 & PP2 & PP3 & PP4 & PP5 & PP6 & PP7 & PP8 & PP9 & PP10 & PP11 \\
\hline PP1 & 1.00000 & $\begin{array}{c}0.77029 \\
<.0001 \\
\end{array}$ & $\begin{array}{r}0.77067 \\
<.0001 \\
\end{array}$ & $\begin{array}{c}0.83876 \\
<.0001 \\
\end{array}$ & $\begin{array}{c}0.68004 \\
<.0001 \\
\end{array}$ & $\begin{array}{c}0.69009 \\
<.0001 \\
\end{array}$ & $\begin{array}{c}0.68566 \\
<.0001 \\
\end{array}$ & $\begin{array}{c}0.72220 \\
<.0001 \\
\end{array}$ & $\begin{array}{c}0.83806 \\
<.0001 \\
\end{array}$ & $\begin{array}{c}0.83412 \\
<.0001 \\
\end{array}$ & $\begin{array}{c}0.83876 \\
<.0001\end{array}$ \\
\hline PP2 & $\begin{array}{c}0.77029 \\
<.0001 \\
\end{array}$ & 1.00000 & $\begin{array}{c}0.92564 \\
<.0001 \\
\end{array}$ & $\begin{array}{c}0.97994 \\
<.0001 \\
\end{array}$ & $\begin{array}{c}0.83593 \\
<.0001 \\
\end{array}$ & $\begin{array}{c}0.87325 \\
<.0001 \\
\end{array}$ & $\begin{array}{c}0.80923 \\
<.0001 \\
\end{array}$ & $\begin{array}{c}0.82714 \\
<.0001 \\
\end{array}$ & $\begin{array}{c}0.98659 \\
<.0001 \\
\end{array}$ & $\begin{array}{c}0.90084 \\
<.0001 \\
\end{array}$ & $\begin{array}{c}0.97994 \\
<.0001\end{array}$ \\
\hline PP3 & $\begin{array}{c}0.77067 \\
<.0001 \\
\end{array}$ & $\begin{array}{c}0.92564 \\
<.0001 \\
\end{array}$ & 1.00000 & $\begin{array}{c}0.95654 \\
<.0001 \\
\end{array}$ & $\begin{array}{c}0.80001 \\
<.0001 \\
\end{array}$ & $\begin{array}{c}0.84170 \\
<.0001 \\
\end{array}$ & $\begin{array}{c}0.67653 \\
<.0001 \\
\end{array}$ & $\begin{array}{c}0.76657 \\
<.0001 \\
\end{array}$ & $\begin{array}{c}0.92151 \\
<.0001 \\
\end{array}$ & $\begin{array}{c}0.76508 \\
<.0001 \\
\end{array}$ & $\begin{array}{r}0.95654 \\
<.0001 \\
\end{array}$ \\
\hline PP4 & $\begin{array}{c}0.83876 \\
<.0001\end{array}$ & $\begin{array}{c}0.97994 \\
<.0001\end{array}$ & $\begin{array}{c}0.95654 \\
<.0001\end{array}$ & 1.00000 & $\begin{array}{c}0.84777 \\
<.0001\end{array}$ & $\begin{array}{c}0.83468 \\
<.0001\end{array}$ & $\begin{array}{c}0.72759 \\
<.0001\end{array}$ & $\begin{array}{c}0.83372 \\
<.0001\end{array}$ & $\begin{array}{c}0.98716 \\
<.0001\end{array}$ & $\begin{array}{c}0.87367 \\
<.0001\end{array}$ & $\begin{array}{c}1.00000 \\
<.0001\end{array}$ \\
\hline PP5 & 0.68004 & 0.83593 & 0.80001 & 0.84777 & 1.00000 & 0.60602 & 0.63760 & 0.96618 & 0.81457 & 0.79594 & 0.84777 \\
\hline
\end{tabular}


Contribution of Pollution Prevention as a Green Supply Chain Practice-A Pilot Empirical Study ....

\begin{tabular}{|c|c|c|c|c|c|c|c|c|c|c|c|}
\hline \multicolumn{12}{|c|}{$\begin{array}{l}\text { Pearson Correlation Coefficients, } \mathrm{N}=50 \\
\text { Prob }>|\mathbf{r}| \text { under H0: } R \text { ho }=0\end{array}$} \\
\hline & $<.0001$ & $<.0001$ & $<.0001$ & $<.0001$ & & $<.0001$ & $<.0001$ & $<.0001$ & $<.0001$ & $<.0001$ & $<.0001$ \\
\hline PP6 & $\begin{array}{c}0.69009 \\
<.0001\end{array}$ & $\begin{array}{c}0.87325 \\
<.0001\end{array}$ & $\begin{array}{c}0.84170 \\
<.0001\end{array}$ & $\begin{array}{c}0.83468 \\
<.0001\end{array}$ & $\begin{array}{c}0.60602 \\
<.0001\end{array}$ & 1.00000 & $\begin{array}{c}0.78397 \\
<.0001\end{array}$ & $\begin{array}{c}0.58548 \\
<.0001\end{array}$ & $\begin{array}{c}0.88628 \\
<.0001\end{array}$ & $\begin{array}{c}0.71378 \\
<.0001\end{array}$ & $\begin{array}{c}0.83468 \\
<.0001\end{array}$ \\
\hline PP7 & $\begin{array}{c}0.68566 \\
<.0001 \\
\end{array}$ & $\begin{array}{c}0.80923 \\
<.0001 \\
\end{array}$ & $\begin{array}{c}0.67653 \\
<.0001 \\
\end{array}$ & $\begin{array}{c}0.72759 \\
<.0001 \\
\end{array}$ & $\begin{array}{c}0.63760 \\
<.0001 \\
\end{array}$ & $\begin{array}{c}0.78397 \\
<.0001 \\
\end{array}$ & 1.00000 & $\begin{array}{c}0.69960 \\
<.0001 \\
\end{array}$ & $\begin{array}{c}0.77247 \\
<.0001 \\
\end{array}$ & $\begin{array}{c}0.90915 \\
<.0001 \\
\end{array}$ & $\begin{array}{c}0.72759 \\
<.0001 \\
\end{array}$ \\
\hline PP8 & $\begin{array}{c}0.72220 \\
<.0001\end{array}$ & $\begin{array}{c}0.82714 \\
<.0001\end{array}$ & $\begin{array}{c}0.76657 \\
<.0001\end{array}$ & $\begin{array}{c}0.83372 \\
<.0001\end{array}$ & $\begin{array}{c}0.96618 \\
<.0001\end{array}$ & $\begin{array}{c}0.58548 \\
<.0001\end{array}$ & $\begin{array}{c}0.69960 \\
<.0001\end{array}$ & 1.00000 & $\begin{array}{c}0.80641 \\
<.0001\end{array}$ & $\begin{array}{c}0.85149 \\
<.0001\end{array}$ & $\begin{array}{c}0.83372 \\
<.0001\end{array}$ \\
\hline PP9 & $\begin{array}{c}0.83806 \\
<.0001 \\
\end{array}$ & $\begin{array}{c}0.98659 \\
<.0001 \\
\end{array}$ & $\begin{array}{c}0.92151 \\
<.0001 \\
\end{array}$ & $\begin{array}{c}0.98716 \\
<.0001 \\
\end{array}$ & $\begin{array}{c}0.81457 \\
<.0001 \\
\end{array}$ & $\begin{array}{c}0.88628 \\
<.0001 \\
\end{array}$ & $\begin{array}{c}0.77247 \\
<.0001 \\
\end{array}$ & $\begin{array}{c}0.80641 \\
<.0001 \\
\end{array}$ & 1.00000 & $\begin{array}{c}0.88674 \\
<.0001 \\
\end{array}$ & $\begin{array}{c}0.98716 \\
<.0001 \\
\end{array}$ \\
\hline PP10 & $\begin{array}{c}0.83412 \\
<.0001 \\
\end{array}$ & $\begin{array}{c}0.90084 \\
<.0001 \\
\end{array}$ & $\begin{array}{c}0.76508 \\
<.0001 \\
\end{array}$ & $\begin{array}{c}0.87367 \\
<.0001 \\
\end{array}$ & $\begin{array}{c}0.79594 \\
<.0001 \\
\end{array}$ & $\begin{array}{c}0.71378 \\
<.0001 \\
\end{array}$ & $\begin{array}{c}0.90915 \\
<.0001 \\
\end{array}$ & $\begin{array}{c}0.85149 \\
<.0001 \\
\end{array}$ & $\begin{array}{c}0.88674 \\
<.0001 \\
\end{array}$ & 1.00000 & $\begin{array}{r}0.87367 \\
<.0001 \\
\end{array}$ \\
\hline PP11 & $\begin{array}{c}0.83876 \\
<.0001 \\
\end{array}$ & $\begin{array}{c}0.97994 \\
<.0001 \\
\end{array}$ & $\begin{array}{c}0.95654 \\
<.0001 \\
\end{array}$ & $\begin{array}{c}1.00000 \\
<.0001 \\
\end{array}$ & $\begin{array}{c}0.84777 \\
<.0001 \\
\end{array}$ & $\begin{array}{c}0.83468 \\
<.0001 \\
\end{array}$ & $\begin{array}{c}0.72759 \\
<.0001 \\
\end{array}$ & $\begin{array}{c}0.83372 \\
<.0001 \\
\end{array}$ & $\begin{array}{c}0.98716 \\
<.0001 \\
\end{array}$ & $\begin{array}{c}0.87367 \\
<.0001 \\
\end{array}$ & 1.00000 \\
\hline
\end{tabular}

\section{Factor Analysis}

Using a statistical analysis software, SAS 9.2, Confirmatory Factor Analysis (CFA) was conducted on the construct Pollution Prevention which consists of 11 variables. Principal Components method was used as the initial factor method. Accordingly the Eigenvalues were obtained as shown in the Table 6.

Table 6. Eigen values obtained by using Principal Components Method as the initial factor method.

\begin{tabular}{|l|l|l|l|l|}
\hline \multicolumn{5}{|c|}{ Eigenvalues of the Correlation Matrix: Total = 11 Average = 1 } \\
\hline & Eigenvalue & Difference & Proportion & Cumulative \\
\hline $\mathbf{1}$ & 9.28741522 & 8.65018820 & 0.8443 & 0.8443 \\
\hline $\mathbf{2}$ & 0.63722703 & 0.12385130 & 0.0579 & 0.9022 \\
\hline $\mathbf{3}$ & 0.51337573 & 0.17991884 & 0.0467 & 0.9489 \\
\hline $\mathbf{4}$ & 0.33345689 & 0.20507633 & 0.0303 & 0.9792 \\
\hline $\mathbf{5}$ & 0.12838056 & 0.05004244 & 0.0117 & 0.9909 \\
\hline $\mathbf{6}$ & 0.07833812 & 0.05653166 & 0.0071 & 0.9980 \\
\hline $\mathbf{7}$ & 0.02180645 & 0.02180645 & 0.0020 & 1.0000 \\
\hline $\mathbf{8}$ & 0.00000000 & 0.00000000 & 0.0000 & 1.0000 \\
\hline $\mathbf{9}$ & 0.00000000 & 0.00000000 & 0.0000 & 1.0000 \\
\hline $\mathbf{1 0}$ & 0.00000000 & 0.00000000 & 0.0000 & 1.0000 \\
\hline $\mathbf{1 1}$ & 0.00000000 & & 0.0000 & 1.0000 \\
\hline
\end{tabular}

From Table 6 it is clear that the first factor can explain 9.28741522 variables. Hence it is a desirable factor. No other factor in the Table 6 can explain at least one variable. Hence the first factor will be retained by MINEIGEN criterion as shown by the factor pattern of Table 7. The variance explained by the factor is 9.2874152 .

Table7. Factor pattern obtained for the single factor retained by MINEIGEN criterion

\begin{tabular}{|l|l|}
\hline \multicolumn{2}{|l|}{ Factor Pattern } \\
\hline & Factor1 \\
\hline PP1 & 0.85799 \\
\hline PP2 & 0.98140 \\
\hline PP3 & 0.93170 \\
\hline PP4 & 0.98115 \\
\hline PP5 & 0.87512 \\
\hline PP6 & 0.85701 \\
\hline PP7 & 0.83138 \\
\hline PP8 & 0.88014 \\
\hline PP9 & 0.98129 \\
\hline PP10 & 0.93041 \\
\hline PP11 & 0.98115 \\
\hline
\end{tabular}

The final communality estimates are shown in Table 8 .

Table 8. The final communality estimates for Pollution Prevention

\begin{tabular}{|l|l|l|l|l|l|l|l|l|l|l|}
\hline \multicolumn{1}{|l|}{ Final Communality Estimates: Total $=9.287415$} \\
\hline PP1 & PP2 & PP3 & PP4 & PP5 & PP6 & PP7 & PP8 & PP9 & PP10 & PP11 \\
\hline 0.736152 & 0.96314 & 0.86806 & 0.9626 & 0.765841 & 0.7344 & 0.6911 & 0.7746 & 0.96293 & 0.86565 & 0.962654 \\
90 & 088 & 067 & 5470 & 61 & 7195 & 9934 & 4951 & 418 & 480 & 70 \\
\hline
\end{tabular}

\section{Conclusion}

The aim of this paper was to study the contribution of the eleven variables constituting the construct Pollution Prevention as a component of Green Supply Chain Practices. It was found that all the eleven variables in the study were strongly correlated with each of the other variables meaning that the variables are strongly 
oriented towards pollution prevention. The reliability of the construct Pollution Prevention was 0.981131 which is considered good. Also the reliability of the eleven variables constituting the construct Pollution Prevention was above 0.9 which means that the questionnaire is reliable to measure each of the variables and also the construct Pollution Prevention as a whole. Also the results of Confirmatory Factor Analysis reveal that one factor accounting for 9.28 variables is retained.

\section{Acknowledgements}

I express my heartfelt thanks to Dr. Abdul Razak Honnutagi for permitting me to go ahead with my research work from NITIE, Mumbai though our institute was at its formative stage. Also I acknowledge the patience and support of my wife Yasmin Mohd.Asif Gandhi for bearing with me during my long research hours for years. I express my heartfelt thanks to my parents Mr. Indravadan Chimanlal Gandhi and Mrs. Sarmista Indravadan Gandhi for encouraging me and motivating me to complete my research work. I dedicate all my success to them. Special thanks to my guide Dr. Sanjay Sharma for inculcating in me the habit of writing original work.

\section{References}

[1] Freeman, H., Harten, T., Springer, J., Randall, P., Curran, M. A., \& Stone, K. (1992). Industrial pollution prevention! A critical review. Journal of the Air \& Waste Management Association, 42(5), 618-656.

[2] Hart, S. L. (1995). A natural-resource-based view of the firm. Academy of management review, 20(4), 986-1014.

[3] Hayes, R. H., \& Wheelwright, S. C. (1984). Restoring our competitive edge: competing through manufacturing.

[4] Gandhi, M.A., A Review of the Indian Automobile Manufacturing Sector, IOSR Journal of Business and Management, 19(3), Ver II, 2017, 9-15.

[5] Gandhi, M.A. and Sharma, S., A Review of Research Methodologies Linking Green Supply Chain Practices and Green Supply Chain Performance, International Journal of Supply Chain Management, 3(4), 2014

[6] Geffen, C. A., \& Rothenberg, S. (2000). Suppliers and environmental innovation: the automotive paint process. International Journal of Operations \& Production Management, 20(2), 166-186.

[7] George D, Mallery M. "Using SPSS for Windows step by step: a simple guide and reference", 2003

[8] Klassen, R. D., \& Whybark, D. C. (1999). The impact of environmental technologies on manufacturing performance. Academy of Management journal, 42(6), 599-615.

[9] Porter, M. E., \& Van der Linde, C. (1995). Green and competitive: ending the stalemate. Harvard business review, 73(5), 120-134.

[10] Royston, M. G. (2013). Pollution prevention pays. Elsevier.

[11] Reinhardt, F. L. (1998). Bringing the environment down to earth. Harvard business review, 77(4), 149-57.

[12] Schmidheiny, S. (1992). With the Business Council for Sustainable Development. Changing course: a global business perspective on development and the environment, 2.

[13] Sharma, S., and Gandhi, M.A., Exploring correlations in components of green supply chain practices and green supply chain performance, Competitiveness Review, 26(3), 2016, 332-368.

[14] Statistics Canada (1996). Environmental Protection Expenditures in the Business Sector, 1994, Ottawa, ON 